\title{
Heidegger, the politics of space, and the space of politics
}

\author{
Florian Grosser \\ Department of Philosophy, University of St. Gallen, Switzerland Department of Philosophy, University of \\ California at Berkeley, USA \\ Correspondence to: Florian Grosser (florian.grosser@unisg.ch)
}

Received: 23 November 2016 - Accepted: 7 December 2016 - Published: 17 February 2017

Accepting Benedikt Korf's kind invitation to assess the pharmacon of Heidegger's thinking, i.e., its poisonous as well as its remedial effects, I am a latecomer to a debate that has been held in this journal over the past two years. At the same time, I am a newcomer to this discussion, since I am unfamiliar with its specific line of questioning, with its guiding interest in reconsidering, in the aftermath of the publication of the Black Notebooks, the dangers and opportunities inherent to deploying Heidegger's philosophical thought on space, region, and place in geographical research. At least at first glance, this perspective seems to be rather far removed from the angle of political philosophy from which I try to approach Heidegger. A second look, however, reveals a nexus that allows one to bridge these disciplinary differences: for Heidegger's topological considerations are repeatedly rich in political implications. In particular, his analyses of Ort, Gegend, and Raum affect the way in which he construes meaningful forms of community.

Taking my cue from the work of Jeff Malpas on spatiality and sociality in Heidegger (cf. Malpas, 2007, 65ff. and 2012, $137 \mathrm{ff}$.), it is my goal to give a brief and selective overview of the ways in which his philosophical topology informs his politics. For this purpose, I will first turn to the "early Heidegger", who, in Being and Time or in several texts written during his activist period in support of Nazism, sees the Volk, the people, as the paradigmatic manifestation of authentic communality. Here, I will critically engage with Heidegger's approach to Dasein's "essential spatiality" by asking what role his general emphasis on that which is near and, more specifically, his notion of "regional belonging" (Heidegger, 2010, 351; cf. GA 2, 368) play for his concept of "folkish Dasein" - a concept of communal homogeneity which, as I will show, is problematic in that it, among other things, facilitates othering and exclusion. In a second step, I will concentrate on the "late Heidegger", who, in texts such as The Thing or Art and Space, comes to conceive meaningful communality differently, i.e., independent of essentially closed notions of a people's belonging. Again, I will pay particular attention to the influence of topological terms such as "regioning" or "expanse" on this shift toward a more permeable, more plural understanding of community as an open "gathering".

The critical question whether Heidegger, in his shifting politics of space, places himself within or without the space of politics will be the main thread of the following remarks. Thereby, the "space of politics" is understood as democratic in a broad sense: it is circumscribed, albeit roughly and in outline, by means of the border stones of, most importantly, non-violence, plurality, and "equaliberty" - a concept used by Étienne Balibar to designate the interrelated, coconstitutive character of the ideals of equality and liberty at the origin of the modern democratic tradition (cf. Balibar, 2014, 35ff. and 99ff.). The attempt to thus situate Heidegger will, I hope, assist critical geographers and others interested in the political aspects of Heidegger's topology in distinguishing between poison and remedy and in determining the right dosage for their research.

I.

The paragraphs in Being and Time in which Heidegger develops his thoughts on spatiality emphasize Dasein's "essential tendency toward nearness" (Heidegger, 2010, 103; cf. GA 2, 105). According to this line of thought, that which is near is encountered by Dasein as particularly significant. This is elaborated upon in detail with regard to things "present-athand" and "ready-to-hand"; although this is not made explicit by Heidegger in the paragraphs in question ( $\$ 22-24)$, this also applies to what he calls "Dasein-with", i.e., to other instances of Dasein that are encountered in the lived experience of spatial - or, more precisely, "environmental" and "regional" - contexts. His rejection of the idea of objective, measurable, and calculable thus implies that Dasein is not 
only affected more but also more meaningfully by those with whom it shares the same concrete contexts, those who belong to the same "worlds". When Heidegger discusses the modern trend, a trend importantly supported by new technologies and media, of overcoming remoteness by means of "de-distancing" that brings with it a "de-worlding" or "deprivation of worldliness", his remarks are ambiguous in that they operate in both a descriptive and an evaluative register. This, for instance, becomes apparent when Heidegger, in a passage that criticizes contemporary attempts to "understand the most foreign cultures" (Heidegger, 2010, 171; cf. GA 2, 178), short-circuits "near" and "own", "remote", and "foreign": with respect to their significance for Dasein, nearness and ownness are privileged over remoteness and foreignness. Paragraph 74 of Being and Time confirms the idea that belonging to a spatial context that is shared with others who are near falls into one with belonging to a community: the Zugehörigkeit to a specific community, the community of the people, emerges from the Hingehörigkeit to a specific spatiotemporal "world". Although the focus is on the temporality of the Volksgemeinschaft, belonging in this latter sense undoubtedly contributes to its non-deficient, unique character as the "complete, authentic occurrence of Dasein" (Heidegger, 2010, 366; cf. GA 2, 385).

This becomes clear in Heidegger's politicalized texts of the 1930s which, revolving around the Volk as the decisive political agent, build upon the reflections of $\$ 74$. Beyond the limited number of openly activist texts, these reflections are also taken up in an ideologized interpretation of Heraclitus's fragment 53 on polemos presented in the 1933-1934 lecture course On the Essence of Truth. There, Heidegger suggests that the unity of the people is predicated on a radical form of dissociation that he discusses under the title of "enmity": he invokes the "fundamental requirement to find the enemy, to expose the enemy [...], or even first to make the enemy" (Heidegger, 2010b, 73; cf. GA 36/37, 91). In these remarks, the topological discourse on belonging resurfaces when Heidegger warns his students that this enemy "can have attached itself to the innermost roots" (ibid.) of the people. This, he goes on, makes it necessary to "bring the enemy into the open, [...] to cultivate and intensify a constant readiness and to prepare the attack looking far ahead with the goal of total annihilation" (ibid.). It is thus implied that this enemy - and who could this refer to if not the German Jews? (cf. Fried, 2016, 53ff.; cf. Grosser, 2015, 204ff.) - "improperly" occupies a place that it does not "originally" belong to. It is evident to what extent these comments, heavily charged with anti-Semitism and sympathetic to unbounded violence against Jews, are enabled by Heidegger's considerations on "authentic" belonging to a "folkishly" defined "world": the (crypto-)normativity inscribed in the semantics of Gehörigkeit ${ }^{1}$ facilitates an ethically untenable, politically

\footnotetext{
${ }^{1}$ This normative dimension of the term is reflected in expressions such as es gehört sich/es gehört sich nicht.
}

eminently dangerous "splitting of humanity into natives and strangers" (Levinas, 1997, 232).

Heidegger's topological discourse also influences the charge of "worldlessness", which he, in the Black Notebooks dating from 1938 to 1939 , levels against Jews. In my view, his comments on the alleged "Weltlosigkeit des Judentums" (Heidegger, 2014a, VIII, 9) constitute an even more grave, more brutal attack than the earlier remarks that present enmity toward the Jews as the raison d'être of the German people. For Heidegger insinuates that the Jews, taken as an instantiation of radical otherness, do not even matter as an inimical counterpart any longer, which, even though ultimately disposable, is instrumental in attaining or heightening what is the Germans" "own". His position as to "worldlessness" that is, as to the Jews not having a "world" and not "beingin-the-world" - seems to be based on the assumption that the Jews somehow lack the capacity to engage in, to at least potentially assert themselves in violent "polemic" confrontation (cf. Grosser, 2015, 208ff.). Attributes like "ungraspability" (Unfassbarkeit) and "emptiness" (Leere) invoked in the Black Notebooks reveal that the Jews, for him, represent a fundamental deficiency or negativity. This alleged deficiency is addressed in topological terminology: taking up a remark on "semitic nomads" from his 1933-34 lecture Über Wesen und Begriff von Natur, Geschichte und Staat and openly alluding to the anti-Semitic stereotype of the Jews as "perpetual wanderers" (cf. Mehring, 2016, 196f.), Heidegger presents "placelessness" (Ortlosigkeit), "groundlessness" (Bodenlosigkeit), and an "utterly unattached" (an nichts gebunden and schlechthin ungebunden) form of life as constitutive elements of their "worldlessness" (cf. Heidegger, 2014a, VIII, 9; Heidegger, 2014b, XIV, 121). His idiosyncratic discourse on locally defined belongingness thus substantively contributes to his aggressive othering of the Jews, which, in combination with a number of further elements of his thought, ${ }^{2}$ enables their characterization as "the opposite of everything" (cf. Trawny, 2014, 53) in the most intransigent manner, i.e., as the opposite of everything that is and has existence in a fulfilled, "historical" sense.

In light of his comments on "enmity" and "worldlessness", it is hardly contestable that Heidegger places himself outside the space of politics when he - not despite, but on the basis of, a philosophical thinking - designates an entire people as the legitimate target of absolute destruction and, ultimately, as subhuman. Thereby, the purported missing placedness, rootedness, and belongingness of the Jews is a crucial enabling factor in the emergence of an ideological position "that connects Heidegger in spirit [...] to one of the greatest crimes in history" (Fried, 2016, 54).

\footnotetext{
${ }^{2}$ For instance, the textual history of "worldlessness" - and, especially, Heidegger's approach to the subject in the 1929-30 lecture The Fundamental Concepts of Metaphysics - needs to be taken into consideration in order to grasp his deeply troubling perspective (cf. Grosser, 2015).
} 
II.

In his later thinking, Heidegger increasingly backs away from the problematic idea that local situatedness essentially predetermines Hingehörigkeit (to one specific place), Zugehörigkeit (to one specific community), and thus "historical" significance. In the following, I will not reconstruct this complex, nonlinear shift in his topological discourse in detail - a shift induced by, among other things, his intellectual engagement with Hölderlin's poetry, which leads him to, e.g., reconsider his understanding of "home", to dynamize it in the processual notion of "homecoming", and to open it for experiences of the "foreign" (cf. Heidegger, 2000; cf. Grosser, 2011, 173ff. and 334ff.). Instead, I will focus on two texts in which his modified philosophical politics of place and space take particularly contoured shape: the 1949 lecture The Thing and the 1969 essay Art and Space.

Heidegger's reframing of the manner in which spatiality and sociality are understood individually and linked with each other manifests itself in a changed concept of community: superseded by the notion of "gathering" that allows for plurality (internally) and for permeability (externally), community is no longer grasped as the (inwardly) radically homogeneous and (outwardly) radically exclusive collective Dasein of the Volk. In the reminder of this paper, I want to sketch how Heidegger, on the one hand, continues his project of a philosophic-topological critique that distinguishes between the neutralized (i.e., objective, representable, measurable, controllable) space of Platonic, Aristotelian, and Cartesian thought and, especially, "the physically-technologically projected space" (Heidegger, 1969, 4; cf. GA 13, 205) of modern science and, in contrast, the meaningful space of "lived" experience, and how he, on the other hand, overcomes the problematically deterministic bias of belonging in the narrow sense (i.e., to a specific place and group) as opposed to belonging to in the wide sense of being "claimed" and "addressed" by being.

In The Thing, Heidegger reconceives place by associating it with "things" as the focal points of "worlds". Contrary to mere objects, "things" have the capacity to "gather" the co-constitutive moments of the "fourfold" (Heidegger, 2012, 11f.; cf. GA 79, 12f.). Besides bringing together "earth" and "sky", "divinities" and "mortals", "things" like a jug - an example reflective of what Claude Raffestin, in his contribution to this debate, aptly calls mystique de la ruralité - also bring together humans and, thus, enable the occurrence of communities: on Heidegger's account, "thinging things" are the centers of spheres or spaces of communality. In assembling humans, such locally and temporally limited spaces make it possible to develop meaningful alternatives (or alternative meanings) beyond mere refusal and rejection with regard to the "planetary" manifestations of modern technology (cf. Dreyfus, 2006, 345ff.). In these considerations, "things" are not only generally expounded as places thick with meaning but also specifically marked as politically significant places of refugee from and resistance to the totalizing "destiny" of technology. As both the boundaries of communal spaces unfolding around such "thing" places and the criteria of belongingness are kept open, Heidegger's altered approach no longer runs the risk of naturalizing and essentializing Hingehörigkeit and Zugehörigkeit.

The interplay between spatiality and sociality also informs the essay Art and Space, which, thus complementing The Thing lecture's more pronounced concern with community, primarily focuses on the former aspect. In this essay, Heidegger attempts to lay bare the contours of "genuine space", i.e., of space in its "essencing". Applying his characteristic method of "listening to language", he suggests that the word "space" (Raum) has to be read in the verbal sense of "clearing away" (räumen) and "making room" (einräu$m e n)$ : thereby, the "primal phenomenon" of space reveals itself as a dynamic happening that "releases places" and, thus, grants "openness". This implies that genuine places are not found everywhere within space ad libitum; instead, they are to be understood as privileged concentration points of significance as it is only around "gathering places" that regions unfold in which humans meaningfully exist. Grasping space in terms of "making room", Heidegger further holds that places cannot be located as if space was a "pre-given" container. Against predominant scientific and technological approaches, he discloses what he refers to as "artistic space": in artistic experience, space "unfolds itself only through the reigning of places of a region" (Heidegger, 1969, 6; cf. GA $13,208)$ - owing to their "gathering" and "regioning" qualities, places allow for space to show itself in a perceptible way. Sculptures, for Heidegger, are paradigmatic places or, as he again identifies the two, "things": a sculpture like Eduardo Chillida's El Peine del Viento "embodies" and "forms" place, "grounds locality", "institutes" habitable "regions", and prepares a stage on which space can become "perceptible with the sense". Even though in Art and Space questions concerning sociality remain in the background of Heidegger's reflections on spatiality, a few indirect political implications are discernible. Most importantly, human belonging to Being is no longer tied to belonging to a place and community defined in terms of the Volk, its "origin" and "heritage". Such belonging, in Heidegger's understanding, is receptively and responsively grasped by artists like Chillida who, in their works, institute significant "thing" places and enable communal "gatherings" to occur in the "width" of open "expanses".

III.

To conclude, the two texts discussed in this section strongly suggest that Heidegger, in his late thinking on space and community, places himself within the space of politics in a broad democratic sense. In opposition to his considerations of the 1920s and 1930s, distinctions between a we placed in in its unique "folkish" world and, therefore, excep- 
tionally "historical" - and a they - "placeless"; "worldless"; and, therefore, "historically" irrelevant - become obsolete. Although Heidegger has no interest in spelling out a philosophical politics of space and place, these late texts display a general compatibility with demands of "equaliberty" in that access to and participation in "gatherings" is non-exclusive and non-hierarchical; with demands of plurality in that individuals are "be-thinged" or "gathered" in diverse ways and, thus, can exist in singular configurations of multiple, varying belonging; and, finally, with the demand of non-violence in that sharp dichotomies of near/own and remote/foreign are overcome, thus precluding radical forms of othering prone to dehumanization and destruction.

Despite the tendencies described in this section, it would be all too easy to play off a dangerous, poisonous "early Heidegger" and a safe, remedial "late Heidegger" against each other with regard to the politics of space transported by his thinking. One the one hand, such a reading would gloss over important insights as to the "lived", involved, and relational experience of space and place gained in his analyses in Being and Time - analyses that, in their emphasis on Hingehörigkeit and Zugehörigkeit conceived in terms of concrete situatedness and nearness, facilitate but do not necessitate Heidegger's subsequent anti-Semitically charged ideological commitments. On the other hand, such a reading would also unduly marginalize problems related to Heidegger's topological politics of the post-war era - problems that are revealed in remarks on, e.g., "displacement" and "homelessness", which are not described as a universal phenomenon but as a fate unique to the German refugees of war.

The caveat that Heidegger's "post-Kehre" thinking continues to transport numerous political shortcomings and dangers is important beyond the question of how he philosophically conceives place and space. To indicate but a few of the profound problems that remain inscribed in his thought after the period of his activism and throughout the post-war years in closing, ${ }^{3}$ Heidegger fails to unambiguously distance himself from Nazi ideology and politics - this, for instance, is reflected when he promotes the simultaneous "affirmation" of "organizing' (i.e., Hitlerian) and "poetic" (i.e., Hölderlinian) forms of "rule" in the Contributions to Philosophy (cf. GA 65, 62). More generally, he fails to develop an adequate philosophical critique of Nazism, which, instead of unreservedly associating it with the allegedly homogeneous "metaphysical" history of the West, grasps and names its uniquely brutal, inhuman character. Finally, Heidegger, due to his inconclusive conceptions of history and action, remains unable of raising the Schuldfrage and of attributing responsibility for the war and the Shoah, which he, in an absurd and cynical distortion of the facts, even describes as an act of Jewish "self-destruction" (cf. GA 97, 284).

\footnotetext{
${ }^{3}$ Elsewhere, I have elaborated upon the problems mentioned here in detail (cf. Grosser, 2011, 180ff. and 334ff.).
}

\section{References}

Balibar, É.: Equaliberty: Political Essays, Durham, Duke University Press, 2014.

Dreyfus, H.: Heidegger on the Connection between Nihilism, Art, Technology, and Politics, in: The Cambridge Companion to Heidegger, edited by: Guignon, Ch., Cambridge, Cambridge University Press, 345-372, 2006.

Fried, G.: The King is Dead, in: Reading Heidegger's Black Notebooks 1931-1941, edited by: Farin, I. and Malpas, J., Cambridge, MIT Press, 45-57, 2016.

Grosser, F.: Revolution denken. Heidegger und das Politische 19191969, München, C.H. Beck, 2011.

Grosser, F.: Selbstheit, Andersheit und die "Möglichkeit des elementalen Bösen". Lévinas' Heidegger-Kritik im Licht der Schwarzen Hefte, in: Heidegger, die Juden, noch einmal, edited by: Trawny, P. and Mitchell, A., Frankfurt, Klostermann, 191214, 2015.

Heidegger, M.: Art and Space [1969], in: Man and World 6, translated by: Seibert, Ch., Bloomington, Indiana University Press, 3-8, 1969.

Heidegger, M.: Elucidations of Hölderlin's Poetry [1936-1968], translated by: Hoeller, K., Amherst, Humanity Books, 2000.

Heidegger, M.: Being and Time [1927], translated by: Stambaugh, J., Albany, State University of New York Press, 2010a.

Heidegger, M.: On the Essence of Truth [1933-34], in: Being and Truth, Heidegger, M., translated by: Fried, G. and Polt, R., Bloomington, Indiana University Press, 65-201, 2010b.

Heidegger, M.: The Thing [1949], in: Bremen and Freiburg Lectures: 'Insight Into That Which Is' and 'Basic Principles of Thinking', edited by: Heidegger, M., translated by: Mitchell, A., Bloomington, Indiana University Press, 5-22, 2012.

Heidegger, M.: Überlegungen VII-XI (Schwarze Hefte 1938-39) [GA 95], edited by: Trawny, P., Frankfurt, Klostermann, 2014a.

Heidegger, M.: Überlegungen XII-XV (Schwarze Hefte 1939-41) [GA 96], edited by: Trawny, P., Frankfurt, Klostermann, 2014b.

Heidegger, M.: Anmerkungen I-V (Schwarze Hefte 1942-48) [GA 97], edited by: Trawny, P., Frankfurt, Klostermann, 2015.

Levinas, E.: Heidegger, Gargarin and Us, in: Difficult Freedom: Essays on Judaism [1963], edited by: Levinas, E., translated by: Hand, S., Baltimore, The Johns Hopkins University Press, 231234, 1997.

Malpas, J.: Heidegger's Topology: Being, Place, World, Cambridge, MIT Press, 2007.

Malpas, J.: Heidegger and the Thinking of Place: Explorations in the Topology of Being, Cambridge, MIT Press, 2012.

Mehring, R.: Heideggers "große Politik", Die semantische Revolution der Gesamtausgabe, Tübingen, Mohr Siebeck, 2016.

Raffestin, C.: De la géographie à la philosophie - aller et retour!, Geogr. Helv., 71, 15-18, doi:10.5194/gh-71-15-2016, 2016.

Trawny, P.: Heidegger und der Mythos der jüdischen Weltverschwörung, 2nd edition, Frankfurt, Klostermann, 2014. 